\begin{tabular}{lcr}
\hline & ANNALES & \\
& & \\
UNIVERSITATIS MARIAE CURIE-SKLODOWSKA & \\
LOL. II & SECTIO M & 2017 \\
\hline
\end{tabular}

Dorota Litwin-Lewandowska

Uniwersytet Marii Curie-Skłodowskiej

\title{
Gruziński epizod w polskiej polityce zagranicznej w okresie prezydentury Lecha Kaczyńskiego (2005-2010)
}

\section{Wstęp}

Geopolityczne położenie państwa polskiego i doświadczenia historyczne wytworzyły i ugruntowały stanowisko, iż Polska jest przedmurzem Europy, naturalnym ze względów geograficznych zabezpieczeniem przed ekspansją Rosji w kierunku zachodnim. W podobnej sytuacji znajdują się inne państwa środkowoeuropejskie. Rekonstrukcja podmiotowości tej części Europy, wraz z uznaniem ważności interesów zamieszkujących ją narodów, stała się więc głównym wyznacznikiem polityki Prezydenta RP Lecha Kaczyńskiego oraz partii Prawa i Sprawiedliwość. Określał ją cel zmiany postrzegania środkowo-wschodniej Europy w kategoriach „strefy buforowej” między Rosją a Niemcami, a działania zmierzały w kierunku: „dekompozycji w myśleniu o Europie Środkowo-Wschodniej"1.

Etykieta "gorszej Europy” dla tej części kontynentu, nadanie jej drugorzędnej roli, w zasadzie zinstrumentalizowanie, powinno budzić oczywisty sprzeciw, a w dalszej kolejności podjęcie racjonalnych działań zmierzających do uzyskania

1 W. Paruch, W obronie interesów narodowych i tożsamości politycznej Europy Środkowo-Wschodniej. Eurorealizm w myśli politycznej Prawa i Sprawiedliwości, [w:] „Rodzinna Europa”. Europejska myśl polityczno-prawna u progu XXI wieku, red. P. Fiktus, H. Malewski, M. Marszał, E-Wydawnictwo Prawnicze i Ekonomiczne. Biblioteka Cyfrowa, Wrocław 2015, s. 417. 
statusu liczącego się partnera w stosunkach międzypaństwowych. Projektowane działania jednoznacznie określały rolę, którą polska polityka zagraniczna powinna przyjąć, jak to ujął Waldemar Paruch: „Ta część kontynentu musi być wyjątkowo aktywna w środowisku międzynarodowym, aby udowodnić, że istnieje w Europie przestrzeń między Niemcami a Rosją, która może być samodzielna i nowoczesna" ${ }^{2}$. Z powyższych konstatacji wynika, iż Rosja stanowiła jeden z najważniejszych, obok Niemiec, punktów odniesienia w polityce zagranicznej, a jej priorytety wyznaczała opozycja wobec pojawiających się ekspansywnych tendencji w polityce zewnętrznej Władymira Putina. Powołując się na słowa Aleksandra Smolara, można stwierdzić, że: „Polska odnajduje swoje miejsce w toczącym się od wieków konflikcie z imperialną Rosją"3.

Uprawnione jest zatem twierdzenie o istnieniu kultury strategicznej państwa ${ }^{4}$, którą w przypadku RP kształtuje między innymi położenie geopolityczne oraz doświadczenia historyczne. Umiejscowienie Polski między Niemcami i Rosją, państwami dysponującymi znacznie większym potencjałem militarnym niż Polska, ze strony których RP niejednokrotnie w historii doświadczyła ekspansywnej polityki, spowodowało ukształtowanie się świadomości bazującej na braku zaufania, ostrożności i być może kompleksie słabszego partnera. Wielokrotnie rozważany problem stosunku do Rosji nie wymaga kolejnego dowodu przeprowadzonego w niniejszym opracowaniu, bardziej interesujący jest jego wpływ na konkretne działania prowadzone przez polskich decydentów. Można zatem mówić o występowaniu syndromu rosyjskiego, a także syndromu zdrady i ofiary. Potraktowane łącznie prowadzą do ukształtowania się stereotypowego myślenia o Rosji, postrzegania jej w kategoriach partnera niegodnego zaufania, wobec którego nakazywana jest szczególna ostrożność, prowadząca nawet do nadmiernej podejrzliwości. Ukształtowana historycznie świadomość społeczna ma wpływ na proces decyzyjny oraz treść podejmowanych decyzji. Alicja Włodkowska-Bagan wylicza szereg konsekwencji syndromu rosyjskiego ${ }^{5}$. Zauważa też, że negatywne konotacje rosyjskie wzmacniane są: „mitami i symbolami

\footnotetext{
2 Ibidem.

3 Idziemy na wojne z Rosja? Z Aleksandrem Smolarem rozmawiał Adam Leszczyński, http://wiadomosci.gazeta.pl/, dostęp 30 IX 2017.

4 Twórca tej kategorii, Jack Snyder, definiuje ją jako: „sumę idei, uwarunkowanych emocjonalnie odpowiedzi i form zwyczajowych zachowań, jakie członkowie narodowej wspólnoty bezpieczeństwa wyznają i podejmują wobec zagrożeń nuklearnych", J. Snyder, The Soviet Strategic Culture: Implications for Limited Nuclear Operations, RAND Publication, Santa Monica 1977, s. 8-9, cyt. za: A. Włodkowska-Bagan, Kultura strategiczna Polski, [w:] Polityka zagraniczna Polski w zmieniajacym się ładzie międzynarodowym: wybrane problemy, red. R. Zięba, T. Pawluszko, Wydawnictwo UJK, Kielce 2016, s. 55.

5 Zob. A. Włodkowska-Bagan, Kultura strategiczna..., op. cit., s. 61.
} 
utrudniającymi ułożenie partnerskich stosunków między państwami. Syndrom ten wzmacnia bliskość geograficzna i niezmienna od wieków sprzeczność interesów, która wydaje się immanentną cechą relacji dwustronnych"6. Dodatkowo, pejoratywny obraz Rosji wzmacniały niektóre prognozy polityczne, zwiastujące ekspansję Rosji na wschód i południe Europy, historycznie pozytywnie zweryfikowane konfliktami zbrojnymi w Gruzji w 2008 roku i na Ukrainie w 2014 roku.

Interesujący poznawczo wydaje się problem zmiany postrzegania usytuowania państwa polskiego na arenie międzynarodowej, wyrażany w idei i działaniach politycznych, zmierzających do zredefiniowania koncepcji „przedmurza Europy” z pasywnej, ochronnej, na aktywną, kreacyjną. Badaniom poddano okres przypadający na prezydenturę Lecha Kaczyńskiego, gdyż wówczas wyraźniej niż w latach wcześniejszych akcentowano rolę Polski w regionie, zwłaszcza w kontekście bezpieczeństwa energetycznego. Realizacja tego celu badawczego wyraża się w hipotezie o sile potencjału Polski dla efektywnej realizacji wytycznych polityki zewnętrznej, zwłaszcza w konfrontacji z interesami Rosji i bez rzeczywistego wsparcia ze strony UE i NATO. Jej weryfikacji posłużył incydent zbrojny rosyjsko-gruziński z 2008 roku. Z metod badawczych zastosowano głównie metodę analizy treści dokumentów, artykułów naukowych, materiałów prasowych i źródeł internetowych oraz syntezę ich wyników, przedstawionych w podsumowaniu tekstu.

\section{Pozycja ustrojowa Prezydenta RP w stosunkach zewnętrznych}

W myśl Konstytucji ustrój państwa polskiego opiera się na zasadzie podziału i równowagi władzy ustawodawczej, wykonawczej i sądowniczej, sprawowanej przez Sejm i Senat, Prezydenta i Radę Ministrów oraz sądy i trybunały ${ }^{7}$. Taka konstrukcja ustrojodawcza stoi w sprzeczności z modelem monolitycznej władzy państwowej i opiera się na systemie hamulców i równowagi (inaczej system wzajemnego hamowania i równoważenia się władz), fundamentem którego jest idea równości władz. Oznacza to w praktyce możliwość posiadania i stosowania instrumentów do powstrzymywania i hamowania działań poszczególnych władz, tak, by nie doprowadzić do przewagi którejkolwiek z nich ${ }^{8}$, a także

6 A. Włodkowska-Bagan, Konfliktowość w stosunkach polsko-rosyjskich jako stygmat geopolityczny, [w:] Geopolityka w stosunkach polsko-rosyjskich, red. S. Bieleń, A. Skrzypek, Oficyna Wydawnicza Aspra-JR, Warszawa 2012, s. 47.

7 Konstytucja Rzeczypospolitej Polskiej z dnia 2 kwietnia 1997 r., art. 10 ust. 1, 2, www.sejm. gov.pl/, dostęp 25 IX 2017.

8 L. Garlicki, Polskie prawo konstytucyjne. Zarys wyktadu, Warszawa 2009, s. 68; P. Ochmann, M. Pisz, Aksjologiczne fundamenty konstytucji Rzeczypospolitej Polskiej, [w:] Prawo konstytucyjne. Kompendium, red. R. Piotrowski, Wydawnictwo C.H. Beck, Warszawa 2014, s. 7. 
zagwarantować bezpieczeństwo obywatelom w dziedzinie ochrony ich praw i wolności. Niezamierzonym skutkiem takiego usytuowania władz względem siebie jest generowanie konfliktów kompetencyjnych w systemie naczelnych instytucji państwowych. W ostatniej dekadzie było to szczególnie widoczne w przypadku realizacji kompetencji Prezydenta w praktyce politycznej w stosunkach zewnętrznych.

Zgodnie z porządkiem konstytucyjnym rolę głowy państwa w zakresie stosunków zewnętrznych determinuje przepis, iż Prezydent RP „stoi na straży suwerenności i bezpieczeństwa państwa oraz nienaruszalności i niepodzielności jego terytorium"9. Wydaje się, że kluczem do określenia źródeł faktycznych prerogatyw Prezydenta RP w polityce zagranicznej jest art. 126, ust. 1 Konstytucji, mówiący o tym, że „Prezydent RP jest najwyższym przedstawicielem Rzeczypospolitej Polskiej i gwarantem ciągłości władzy państwowej" oraz cytowany powyżej ust. 2, w którym ustawodawca określił zadania głowy państwa, obligując jednocześnie Prezydenta do wspólnego działania z innymi organami władzy państwowej. Oznacza to, że Prezydentowi nie przysługuje wyłączność w ich realizacji w żadnej z form władzy, nie może też działać $\mathrm{w}$ sposób dowolny ${ }^{10}$. Zgodnie z wykładnią prawa konstytucyjnego, Konstytucja RP wyraźnie rozgranicza kompetencje organów egzekutywy, to znaczy, że art. 126 nie posiada charakteru przepisu kompetencyjnego, a jest wskazaniem ogólnych linii ustrojowych. W dziedzinie stosunków zewnętrznych Prezydent „reprezentuje” państwo poza granicami ${ }^{11}$. Mimo to jego rola w stosunkach zewnętrznych jest niedookreślona normatywnie i tym samym rodzi dwojakiego rodzaju interpretacje. Spór dotyczy bowiem problemu: czy Prezydent RP jest organem reprezentującym państwo, czy organem władczym w państwie. Skoro ustawa zasadnicza tego w klarowny sposób nie wyjaśnia, rozwiązanie dylematu może nastąpić poprzez uzgodnienia i wypracowanie uzusu na poziomie praktycznym. Tak ukształtowany system określany jest mianem mieszanego, ponieważ łączy elementy systemu parlamentarno-prezydenckiego i parlamentarno-gabinetowego ${ }^{12}$.

Uprawnienia Prezydenta w stosunkach zewnętrznych są raczej enigmatyczne $\mathrm{w}$ relacji do usytuowania w systemie najważniejszych instytucji państwowych, a przepis, że jest on: „najwyższym przedstawicielem RP”, jeszcze niczego nie wy-

\footnotetext{
${ }^{9}$ Konstytucja..., op. cit., art. 126, ust. 2.

${ }^{10}$ L. Mażewski, Prowadzenie polityki zagranicznej w Rzeczypospolitej Polskiej, „Ruch Prawniczy, Ekonomiczny i Socjologiczny", 2009, R. LXXI, z. 3, s. 11.

${ }^{11}$ J. Jaskiernia, Współdziałanie Prezydenta i Rady Ministrów w sferze polityki zagranicznej, „Państwo i Prawo”, 2010, 6, s. 3-4.

${ }^{12}$ M. Grzybowski, System rząów w Rzeczypospolitej Polskiej: charakterystyka i diagnoza watpliwości. Uwagi wprowadzające, „Przegląd Prawa Konstytucyjnego”, 2012, 1, s. 130.
} 
jaśnia, nie zawierają się w nim żadne przesłanki normatywne, raczej nominalne ${ }^{13}$. Jako reprezentantowi państwa na zewnątrz przysługuje mu: 1) prawo ratyfikowania i wypowiadania umów międzynarodowych;2) mianowania i odwoływania przedstawicieli RP w innych państwach i przy organizacjach międzynarodowych; 3) przyjmowania listów uwierzytelniających i odwołujących akredytowanych przy nim przedstawicieli dyplomatycznych obcych państw i międzynarodowych organizacji (art. 133, ust. 1) ${ }^{14}$. Należy potraktować te uprawnienia jako szczególne, które wymagają konstytucyjnego umocowania ${ }^{15}$. Ponadto w zakresie polityki zagranicznej Prezydent jest konstytucyjnie zobligowany do współdziałania z Prezesem Rady Ministrów i ministrem resortowym „w granicach i na podstawie decyzji Rady Ministrów co do prowadzonej polityki zagranicznej"16. Konstytucja stanowi, iż władza wykonawcza jest pełniona wespół przez Prezydenta i Radę Ministrów ${ }^{17}$. Rząd również na podstawie art. 146, ust. 1 „prowadzi politykę wewnętrzną i zagraniczną Rzeczypospolitej Polskiej”" ${ }^{18}$. Ustawodawca wyznaczył szczególną rolę w zakresie prowadzenia polityki zagranicznej także Ministrowi Spraw Zagranicznych ${ }^{19}$, obligując ten organ do realizacji polityki zewnętrznej rządu. W praktyce politycznej, aby państwo mogło efektywnie realizować politykę zagraniczną, konieczna jest więc współpraca w triadzie Prezydent - Premier - Minister Spraw Zagranicznych.

Prowadzenie polityki zagranicznej ustawodawca powierzył Radzie Ministrów, natomiast rolą Prezydenta jest dbałość o wartości i zasady, o których mówi art. 126 ustawy zasadniczej. Tym samym stworzono wspólną płaszczyznę interakcji Prezydenta, premiera i ministrów resortowych. W komentarzu Paweł Sarnecki stwierdził, że to rząd posiada pełnię władzy w stosunkach międzynaro-

${ }^{13}$ P. Sarnecki: Komentarz do art. 126, [w:] Konstytucja Rzeczypospolitej Polskiej. Komentarz, t. I, red. L. Garlicki, Wydawnictwo Sejmowe, Warszawa 1999, s. 5.

${ }^{14}$ Konstytucja..., op. cit., art. 133, ust. 1. Prezydentowi RP przysługuje też prawo wprowadzenia stanu wojennego na części lub całości terytorium państwa polskiego w sytuacji zagrożenia zewnętrznego państwa, napaści lub w wyniku zobowiązania wspólnej obrony przeciwko agresji, wynikającego z umowy międzynarodowej. Prezydent wprowadza stan wyjątkowy na wniosek Rady Ministrów, Konstytucja..., op. cit., art. 229.

${ }^{15}$ M. Masternak-Kubiak, A. Preisner, Realizacja podziału kompetencji organów państwa w stosunkach zewnętrznych, [w:] Otwarcie Konstytucji RP na prawo międzynarodowe i procesy integracyjne, red. K. Wojtowicz, Wydawnictwo Sejmowe, Warszawa 2006, s. 110.

${ }^{16}$ Konstytucja..., op. cit., art. 133, ust. 3; M. Masternak-Kubiak, A. Preisner, op. cit., s. 110.

${ }^{17}$ Konstytucja..., op. cit., art. 10, ust. 2.

${ }^{18}$ Ibidem, art. 146, ust. 1.

${ }^{19}$ Kompetencje Ministra Spraw Zagranicznych określa Ustawa z 4 września 1997 r. o działach administracji rządowej oraz rozporządzenia Prezesa Rady Ministrów z 1 lipca 2002 r. w sprawie szczegółowego zakresu działania Ministra Spraw Zagranicznych, zob. Dz. U. nr 141, poz. 943; Dz. U. nr 122, poz. 1344. 
dowych, a rola Prezydenta jest ograniczona i nie może wykraczać poza kompetencje nakreślone w art. $126^{20}$. Także orzecznictwo Trybunału Konstytucyjnego jest jednoznaczne: „Prezydent Rzeczypospolitej Polskiej nie ma wynikających wprost z konstytucji uprawnień służących samodzielnemu prowadzeniu polityki zagranicznej Rzeczypospolitej”21.

Intencją ustawodawcy zapewne nie było doprowadzanie do konfliktogenności we władzach wykonawczych, przeciwnie, unikanie nakładania się kompetencji, powielania działań oraz rywalizacji w ramach pełnienia władzy wykonawczej. Co prawda założenie zgodności co do idei, celów, zadań i konkretnych działań w polityce zagranicznej jest ideą szczytną, także racjonalną, by w stosunkach zewnętrznych organy władzy wykonawczej reprezentowały tożsame stanowisko ${ }^{22}$, ale jednocześnie trudną do osiągnięcia, jak pokazała praktyka sprawowania władzy. L. Garlicki podkreśla, że zmianom na scenie politycznej, tj. mniejszościowemu rządowi PiS, wspólnemu rodowodowi politycznemu Premiera i Prezydenta oraz konfliktogenności w stosunkach PO - PiS towarzyszyła: „ewolucja faktycznej roli i autorytetu głowy państwa" do tego stopnia, iż wbrew przepisom konstytucyjnym zyskał on zdecydowanie silniejszą pozycję niż normatywnie określona ${ }^{23}$.

W latach 2005-2007 Rada Ministrów i Prezydent posiadali ten sam rodowód polityczny, w związku z czym prowadzenie polityki zagranicznej nie charakteryzowała konfliktowość, w przeciwieństwie do okresu późniejszego, 2007-2010. W tym przedziale czasowym premier i rząd wywodzili się z ugrupowania konkurencyjnego względem głowy państwa, istniała więc kohabitacja znacznie utrudniająca prowadzenie polityki zagranicznej ${ }^{24}$, z dużym prawdopodobieństwem można stwierdzić, iż był to jeden z trudniejszych przypadków we władzy wykonawczej, niejednokrotnie zdominowanej przez konflikty o prymat w stosunkach zewnętrznych.

Praktyka realizacji przepisów konstytucyjnych unaoczniła, że: „Przy tożsamości konstytucyjnych unormowań odnoszących się do gestii i kompetencji pozosta-

${ }^{20}$ P. Sarnecki, Komentarz do art. 126, op. cit., s. 4.

${ }^{21}$ I dalej: „Nie jest też upoważniony do samodzielnego prowadzenia polityki zagranicznej ani do sprawowania kierownictwa w dziedzinie stosunków z organizacjami międzynarodowymi. Zadania Prezydenta, określone w art. 126 ust. 2, jak też kompetencje wskazane w art. 133 ust. 1 konstytucji wykazują szereg odniesień do sfer polityki: zagranicznej, wewnętrznej oraz unijnej, prowadzenie których pozostaje w gestii Rady Ministrów", Orzeczenie TK z 20 maja 2009 r., Kpt 2/08, http://trybunal.gov.pl, dostęp 10 X 2017.

22 B. Banaszak, Prawo konstytucyjne, Warszawa 2001, s. 566; L. Garlicki, Konstytucja a „sprawy zewnętrzne”, „Przegląd Sejmowy”, 2007, nr 4, s. 197.

${ }^{23}$ L. Garlicki, Konstytucja..., op. cit., s. 198.

${ }^{24}$ Nie był to odosobniony przypadek w historii politycznej Polski, kohabitacja występowała kilkakrotnie, w l. 1993-1995 Lech Wałęsa i rząd PSL-SLD; 1997-2001 Aleksander Kwaśniewski i AWS-UW; 2005 A. Kwaśniewski i PiS; 2007-2010 L. Kaczyński i PO-PSL; 2015 Andrzej Duda i PO-PSL. 
jących w stanie kohabitacji organów praktyka kształtowania się relacji pomiędzy dwoma instytucjami (segmentami władzy wykonawczej) wykazała ewidentne zróżnicowania z następstwami w postaci ujawnionych rozbieżności, obopólnej krytyki, dystansu, a nawet sporu kompetencyjnego ${ }^{25}$. Istnieją dwa wzorce wypracowane w efekcie niedookreśloności prawa i kohabitacji, pierwszy - koncyliacyjny, powstały w okresie prezydentury A. Kwaśniewskiego i rządu Jerzego Buzka, drugi - dystansowo-konkurencyjny między prezydentem L. Kaczyńskim i Donaldem Tuskiem $^{26}$. Antoni Dudek podkreśla, iż przyczynkiem do konfliktów w przestrzeni polityki zagranicznej pomiędzy prezydentem Kaczyńskim a premierem Tuskiem był wadliwy ustrój polityczny III RP, a dokładniej tzw. dwugłowa egzekutywa ${ }^{27}$.

\section{Gruzja w polityce wschodniej Lecha Kaczyńskiego}

Prezydentura L. Kaczyńskiego rozpoczęła się w zupełnie innych uwarunkowaniach systemowych niż L. Wałęsy czy A. Kwaśniewskiego, ponieważ od 1 maja 2004 roku Polska była pełnoprawnym członkiem UE, a od 12 marca 1999 roku NATO. Dotychczasowe priorytety polskiej polityki zagranicznej były wyznaczane przez zorientowanie na Zachód, determinowane przystąpieniem do północnoatlantyckich i unijnych struktur, i zakończone sukcesem. Ta orientacja wymagała kontynuacji, ale także umacniania pozycji Polski w Europie, zgodnie ze statusem jednego z sześciu państw o największym potencjale oraz unijnego lidera dla środkowoeuropejskich krajów. Do trzeciego kwartału 2017 roku pozycji tej nie udało się osiągnąć, niemniej, jak twierdzi A. Dudek, cel ten pozostaje: „częścią testamentu politycznego prezydenta i realnym zadaniem dla jego następcy”28.

W przemówieniu inauguracyjnym z 23 grudnia 2005 roku Prezydent L. Kaczyński określił dwa zasadnicze kierunki polityki zagranicznej państwa polskiego: stosunki ze Stanami Zjednoczonymi i Unią Europejską, podkreślając jednocześnie aspekt współpracy z rządem oraz charakter tej polityki w ten sposób, że: „musi być energiczna (...), nie możemy ograniczyć się do obrony bieżących interesów" ${ }^{29}$. Prezydent podkreślał też aspekt ścisłego i zinstytucjonalizowanego współdziałania państw członkowskich UE. O ile orientacja na współpracę

${ }^{25}$ M. Grzybowski, System rządów..., op. cit., s. 146.

${ }^{26}$ Ibidem.

27 A. Dudek, Gtównym terenem rywalizacji prezydenta Lecha Kaczyńskiego i rzadu Donalda Tuska stała się polityka zagraniczna, https://wpolityce.pl/, dostęp 9 X 2017.

${ }^{28}$ A. Dudek, O prezydenturze Lecha Kaczyńskiego, http://muzhp.pl/, dostęp 11 X 2017.

${ }_{29}^{29}$ Przemówienie inauguracyjne Prezydenta RP Lecha Kaczyńskiego z dnia zaprzysiężenia na Prezydenta RP z dnia 23.12.2005 r., Warto być Polakiem. Idea i myśl Lecha Kaczyńskiego, oprac. zbior., Wydawnictwo KPRP, Warszawa 2010. 
z państwami Europy Zachodniej została raczej ogólnikowo przedstawiona, o tyle więcej uwagi Prezydent poświęcił na wskazanie partnerów na wschodzie i południu Europy (Rosję, Ukrainę, Białoruś, Litwę, Łotwę, Estonię, Czechy, Słowację, Węgry), co można zinterpretować jako dominujące preferencje w kierunkach polityki zagranicznej: „Nową jakość trzeba nadać także temu wszystkiemu, co wiąże się z naszymi stosunkami z krajami leżącymi na wschód od naszych granic"30. Prezydent wyjaśniał koncepcję polityki południowo-wschodniej, sięgającej aż po Azerbejdżan, budowaniem bezpiecznej pozycji Polski w Europie: „Mocna pozycja na Wschodzie to mocniejsza pozycja w Unii, a to z kolei, wraz z dobrymi stosunkami z USA, mocniejsza pozycja wobec Moskwy" ${ }^{31}$. Tak ukształtowany blok nie tylko mógłby stworzyć przestrzeń między Niemcami i Rosją, ale również kształtować politykę zewnętrzną Unii Europejskiej wobec Rosji w sposób korzystny dla wszystkich państw regionu ${ }^{32}$.

W okresie swojej prezydentury L. Kaczyński wielokrotnie akcentował konstruowanie bliskich i partnerskich relacji z państwami Europy Środkowo-Wschodniej i w tym celu odbył szereg podroży zagranicznych na wschód i południe Europy ${ }^{33}$ : „Szukajmy Europy partnerskiej, w której naszemu krajowi należy się miejsce wynikające z jego wielkości i historii”34. Za szczególnie ważne postrzegał relacje z sąsiednią Ukrainą ${ }^{35}$.

${ }^{30}$ Dalsza część cytatu: „Strategiczny sojusz z Ukrainą powinien nabrać bardziej konkretnych kształtów. Ścisła współpraca z Litwą, a także Łotwą i Estonią, czyli pozostałymi krajami nadbałtyckimi, i dążenie do nadania im trwałego charakteru, to nasze cele. Wielkie znaczenie ma także obrona praw obywatela na Białorusi, w tym szczególnie obrona praw polskiej mniejszości. Żywą treść trzeba nadać porozumieniu wyszehradzkiemu naszym stosunkom z Republiką Czeską, Republiką Słowacką oraz Węgrami. Wiele wskazuje na to, iż niewykorzystane są możliwości współpracy z państwami skandynawskimi, szczególnie w odniesieniu do sytuacji na Morzu Bałtyckim. Istotną kwestią są nasze stosunki z Rosją, która pozostaje od wieków, mimo zmiennych kolei losu, naszym wielkim sąsiadem. Patrzymy na nie, uwzględniając przede wszystkim historyczną perspektywę, zachowując cierpliwość i przekonanie, że nie ma obiektywnych powodów, dla których nie mogłyby być one dobre". Ibidem.

${ }^{31}$ Ł. Warzecha, Lech Kaczyński - ostatni wywiad, Prószyński i S-ka, Warszawa 2010, s. 242.

32 W. Paruch, op. cit., s. 421.

${ }^{33}$ Najczęściej odwiedzanym krajem była Litwa (16), także Belgia i Ukraina (9), następnie Czechy i Niemcy (8), Gruzja (7), Węgry (4), Łotwa, Rumunia i Słowacja (3), Chorwacja, Serbia i Estonia (2) oraz Rosja, Bułgaria, Macedonia (1).

${ }^{34}$ Wystąpienie pod pomnikiem Poległych i Pomordowanych na Wschodzie w Warszawie, 17 września 2009 roku, Warto być Polakiem. Idea i myśl Lecha Kaczyńskiego, oprac. zbior., Wydawnictwo KPRP, Warszawa 2010, s. 43.

${ }^{35}$ Problem dyskusyjnych kart z historii stosunków polsko-ukraińskich stanowił zbiór wspólny części programowej polityki wschodniej i polityki historycznej Prezydenta. Dążył on do otwartości i dojrzałej refleksji nad wspólną historią, a celem nadrzędnym było umacnianie partnerstwa z Ukrainą w kontekście ekspansjonizmu rosyjskiego: „Mocne i trwałe pojednanie można bowiem zbudować tylko w oparciu o prawdę. Nie możemy zmienić przeszłości, ale mo- 
O ile można nie stawiać pytań o zasadność współpracy polsko-ukraińskiej, bo ta z oczywistych względów jest racjonalna, o tyle wywołuje zapytania o celowość zainteresowania Gruzją. Polacy i Gruzini nie posiadali szczególnie obfitych wzajemnych relacji w przeszłości historycznej, niemniej można wskazać na wydarzenia, które przesądziły o dobrych stosunkach bilateralnych w teraźniejszości. Takim szczególnym momentem był okres II RP, zwłaszcza lata 1917-1920. W tym czasie Gruzja, w przeciwieństwie do Polski, znalazła się pod silnymi wpływami rosyjskimi ${ }^{36}$. W okresie wprowadzania narodowego komunizmu stalinowskiego, do Polski w latach 1920-1939 napłynęło szereg uchodźców politycznych, szukających schronienia przed prześladowaniami. Obrona przed imperializmem rosyjskim była jednym z priorytetów polityki wschodniej Józefa Piłsudskiego, który planował zbudować sojusz z państwami zakaukaskimi, Gruzją, Armenią i Azerbejdżanem. Polska uznała niepodległość Gruzji w styczniu 1920 roku, proklamowaną w maju 1918 roku. W ramach sojuszu wojskowego z Gruzją, w wojsku polskim w latach 1920-1939 służyli oficerowie kontaktowi - Gruzini, głównie jako kawalerzyści, ale istniała też współpraca w ramach wywiadu i kontrwywiadu. II RP w ramach koncepcji „polityki prometejskiej” nawiązywała współpracę i udzielała pomocy wszystkim nierosyjskim narodom (na przykład Gruzinom, Czeczenom), reprezentującym dążenia irredentystyczne i wolnościowe, bazując na fundamencie przekonania, iż tylko słaba, podzielona Rosja zwiększy bezpieczeństwo polityczne i militarne Polski ${ }^{37}$. Polityka L. Kaczyńskiego odwoływała do tej koncepcji. Po rozpadzie bloku wschodniego nawiązanie stosunków dyplomatycznych między Polską a Gruzją nastąpiło 28 kwietnia 1992 roku, Gruzja odzyskała niepodległość na fali wydarzeń „jesieni ludów” w 1991 roku.

Akcentowanie znaczenia obszaru położonego między Niemcami i Rosją dla UE w kontekście stosunków z Moskwą było jednym z elementów programu partii Prawa i Sprawiedliwość, wyznaczającego warunki konsolidacji Europy Środkowo-Wschodniej. Co prawda program PiS z 2005 roku nie wskazuje bezpośrednio na Gruzję jako partnera strategicznego, jednak można wywnioskować fakt ten z założeń programowych. Dotyczy to na przykład bezpieczeństwa energetycznego

\footnotetext{
żemy sprawić, by nie determinowała przyszłości”, Przemówienie na uroczystości odstonięcia i poświęcenia pomnika ku czci ofiar tragedii w Pawłokomie na Rzeszowszczyźnie, 13 maja 2006 roku, Warto być Polakiem..., op. cit., s. 60-61.

${ }^{36}$ Gruzja została podporządkowana przez bolszewików ostatecznie w 1921 roku, a od marca następnego roku weszła w skład Zakaukaskiej Republiki Radzieckiej, stan ten trwał do 1936 roku.

${ }^{37}$ S. Chazbijewicz, Dlaczego Gruzja? Relacje polsko-gruzińskie wczoraj i dziś, „Debata”, 2008, 6, 9, s. 9-10; zob. też: M. Włodarczyk, Stosunki polsko-gruzińskie w latach 1918-1921, „Świat Idei i Polityki”, 2016, t. 15(26), passim.
} 
Polski: „Możemy to osiągnąć jedynie poprzez uniezależnienie Polski od importu rosyjskiego gazu"38, co wskazuje na poszukiwanie alternatywnych dostawców. Spośród państw basenu Morza Kaspijskiego i Czarnego Gruzja jako jedyna nie posiada złóż gazu i ropy naftowej, natomiast jest to kraj tranzytowy pomiędzy Ukrainą a Azerbejdżanem, a zwłaszcza z partnerem ukraińskim Prezydent wiązał szczególne nadzieje. W jego politycznych planach leżało związanie azerskich elit z państwem polskim, głównie z powodu dostępu do zasobów energetycznych. Gruzja była jedynym z państw niedysponującym zasobami gazu, ale położenie geograficzne i konfliktowe stosunki z Rosją pozwalały na włączenie Gruzji do kręgu państw partnerskich ${ }^{39}$. Wskazanie na Gruzję zapisano w programie PiS na 2007 rok w kontekście wspierania jej dążeń do przystąpienia do NATO, a także podkreśleniem wzmocnienia UE poprzez zacieśnianie współpracy z państwami Kaukazu i Zakaukazia ${ }^{40}$. Dobitniej wyrażał to program z 2009 roku, podkreślający, że Polska jako członek Sojuszu będzie optować za formułą „otwartych drzwi” dla kolejnych państw, które będą chciały do niego przystąpić, szczególnie dla Ukrainy i Gruzji" ${ }^{41}$, także dla Mołdawii i państw południowego Kaukazu, ponieważ rozszerzenie NATO jest jednym z „najpoważniejszych zadań w regionie, w którym Polska powinna aktywnie uczestniczyć" ${ }^{\prime 2}$. Kontynuację współpracy z Gruzją podkreślano też w kontekście bezpieczeństwa energetycznego Polski ${ }^{43}$. Należy dodać, iż, na szczycie NATO w Bukareszcie w kwietniu 2008 roku, Gruzji i Ukrainie odmówiono programu prowadzącego do członkostwa, tzw. MAP (Plan Działań na Rzecz Członkostwa), głównie z powodu zdecydowanego sprzeciwu Rosji ${ }^{44}$. Położenie geograficzne Gruzji powoduje, iż jest ona liczącym się obiektem na mapie strategicznych interesów Rosji w obszarze Kaukazu i Zakaukazia, głównie z powodu możliwości odcięcia Europy, w tym Polski, od złóż ropy naf-

${ }^{38}$ IV Rzeczpospolita. Sprawiedliwość dla wszystkich, Prawo i Sprawiedliwość. Program 2005 roku, s. 48, http://old.pis.org.pl/dokumenty, dostęp 15 IX 2017.

${ }^{39}$ Ł. Warzecha, Lech Kaczyński..., op. cit., s. 243.

40 „Unijna polityka sąsiedztwa musi zostać zrównoważona silniejszym niż dotychczas zaangażowaniem UE w obszarze Europy Wschodniej oraz Południowego Kaukazu i Zakaukazia. Polska dyplomacja udzieli wsparcia działaniom Głowy Państwa w tym regionie. Jesteśmy zwolennikami budowania szybkich i pewnych perspektyw członkostwa w strukturach euroatlantyckich, w szczególności dla Ukrainy, Mołdawii, Gruzji, ale również innych partnerów w regionie Azerbejdżanu, Armenii, a w przyszłości Białorusi", Dbamy o Polskę. Dbamy o Polaków, Prawo i Sprawiedliwość, Program 2007, s. 53, http://old.pis.org.pl/dokumenty, dostęp 15 IX 2017.

${ }^{41}$ Nowoczesna, solidarna, bezpieczna Polska. Program Prawa i Sprawiedliwości, Materiały KW Prawo i Sprawiedliwość, Wydawnictwo Prawo i Sprawiedliwość, Kraków 2009, s. 174.

${ }^{42}$ Ibidem, s. 181.

${ }^{43}$ Ibidem, s. 174.

${ }^{44}$ G. Kuczyński, M. Tomaszewski, Szczyt NATO w Bukareszcie, https://www.tvn24.pl/, dostęp 22 IX 2017. 
towej z basenu Morza Kaspijskiego, także izolacji Armenii i Azerbejdżanu od wpływów europejskich, a w konsekwencji otwarcia na ściślejszy sojusz z Iranem czy oskrzydlenia Ukrainy od południa w przypadku ekspansji na jej terytorium. Nie bez znaczenia jest także obecność Rosjan jako mniejszości na terenach tych państw ${ }^{45}$. Kandydaturom sprzeciwiły się też Niemcy, Francja, Belgia, Holandia, Włochy, Portugalia i Turcja, natomiast USA, Kanada, Polska, Litwa, Łotwa, Estonia, Bułgaria, Rumunia, Słowenia, Słowacja i Czechy opowiedziały się za przyjęciem ${ }^{46}$. Ze względów taktycznych decyzja o członkostwie została odsunięta w czasie $^{47}$. Po zakończonym szczycie L. Kaczyński stwierdził, iż musieliśmy: „z merytorycznego punktu widzenia walczyć o każde słowo w ostatecznym tekście oświadczenia"48.

Można byłoby zaryzykować stwierdzenie, że wybuch konfliktu rosyjskogruzińskiego był nieprzewidywanym zdarzeniem losowym, który dał input L. Kaczyńskiemu do zamanifestowania roli polskiej polityki w Europie, a jednym z jej celów było przeciwstawienie się ekspansji Rosji, a także dowodem na to, że wschodnie mocarstwo ma w planach restytucję kształtu polityki zagranicznej sprzed pierestrojki. Mało realne do spełnienia prognozy polityczne okazały się faktem i stąd „w polskiej polityce zagranicznej oraz polityce bezpieczeństwa i obronności musimy uwzględniać możliwość spełnienia się scenariuszy, które jeszcze do niedawna wydawały się bardzo mało prawdopodobne"49. Wojna rosyjsko-gruzińska potwierdziła strategiczne plany Rosji, zmierzające w kierunku ugruntowania stref wpływów i samodzielnego działania na terenach istotnych dla interesów rosyjskich ${ }^{50}$. Na konfliktogennym obszarze Kaukazu Południowego i basenu Morza Kaspijskiego Rosja planowała utrzymać swoje przywództwo, zwłaszcza że posiadał on atuty strategiczne dla niej w postaci złóż ropy i gazu przesyłanych do Europy. Gruzja była niemalże idealnym miejscem do zaznaczenia swojej strefy wpływów, jako jedyna miała orientację zachodnioeuropejską i od wieków była w konflikcie z Rosją, głównie za sprawą Osetii Południowej. Można też postawić tezę, że szczyt NATO z kwietnia 2008 roku przyśpieszył tylko inwazję rosyjską.

${ }^{45}$ S. Chazbijewicz, O stosunkach polsko-gruzińskich, „Debata”, 2008, nr 9(12), s. 10.

${ }^{46}$ G. Kuczyński, Czy NATO otworzy sięna Wschód?, https://www.tvn24.pl/, dostęp 22 IX 2017.

${ }^{47}$ Podczas szczytu NATO w Newport we wrześniu 2014 roku Ukraina i Gruzja po raz kolejny nie zostały objęte MAP. P. Henzel, Wracaja kontrowersje wokót szczytu NATO w Bukareszcie. „Nowa linia podziatu” w Europie, http://wiadomosci.onet.pl/, dostęp 22 IX 2017.

${ }^{48}$ R. Romaniec, Bilans szczytu NATO w Bukareszcie, http://www.dw.com/pl/, dostęp 22 IX 2017.

${ }^{49}$ Nowoczesna, solidarna, bezpieczna..., op. cit., s. 173.

${ }^{50}$ D. Brążkiewicz, Wojna rosyjsko-gruzińska, htpp://www.geopolityka.org/, dostęp 11 IX 2017. 
Argumentem za podjęciem inicjatywy dyplomatycznej przez Polskę w Gruzji była wyraźna dysproporcja potencjałów siły między Gruzją a Rosją, szczególnie widoczna w momencie ataku. Także obrona państwa, które, mimo iż opiera się na elitach ukształtowanych przez reżim radziecki, preferuje zachodnie wartości demokratyczne i w tym duchu konstytuuje własną państwowość. Ponadto L. Kaczyński podawał w uzasadnieniu, że jest wyraźne podobieństwo w sytuacji Polski z okresu, gdy znajdowała się ona w strefie wpływów sowieckich. W imię często podnoszonego przez prezydenta partnerstwa europejskiego, Gruzja nie powinna być pozostawiona sama sobie, zwłaszcza że, jak podkreślał L. Kaczyński, państwo gruzińskie jest jednym z etapów procesu rekonstrukcji strefy wpływów rosyjskich w Europie ${ }^{51}$.

Otwarty konflikt zbrojny w Gruzji był krótkotrwały, można określić go mianem incydentu czy epizodu, trwał zaledwie kilka dni, od 7 do 12 sierpnia 2008 roku. Został on poprzedzony manewrami rosyjskimi „Kaukaz 2008” oraz ostrzelaniem baz gruzińskich. Jego dokładny przebieg nie znajduje się w przedmiocie niniejszego opracowania, poza przedstawieniem podstawowych informacji o konflikcie. Gruzja została zaatakowana przez wojska rosyjskie oraz separatystów z Osetii Południowej i Abchazji, choć w mediach podawano informacje o gruzińskiej prowokacji. Kontrolowane i wspomagane militarnie przez Moskwę Osetia i Abchazja były terenami spornymi, wybitnie konfliktogennymi, na których bezskutecznie próbowano zaprowadzić pokój, niejednokrotnie wykorzystywanymi do realizacji celów politycznych Rosji. Moskwa od dawna przygotowywała się do tej interwencji, planując upozorowanie ataku gruzińskiego poprzez ostrzał Cchinwali. W odpowiedzi Gruzini zbombardowali budynki rządowe, wówczas Rosja wkroczyłaby oficjalnie w obronie własnej mniejszości narodowej i mogłaby prowadzić regularną walkę ${ }^{52}$.

Kulminacyjnym momentem wojny była decyzja L. Kaczyńskiego o wspólnej interwencji szefów państw sąsiadujących z Rosją, w celu oprotestowania pogwałcenia prawa międzynarodowego i brutalnej napaści na Gruzję, a przede wszystkim zachowania integralności terytorialnej oraz niepodległości Gruzji.

${ }^{51}$ GK, PAP, „Rzeczpospolita”, Z Rosja trzeba ostro. Rozmowa z Prezydentem Lechem Kaczyńskim, http://www.newsweek.pl/, dostęp 17 X 2017.

${ }^{52}$ I. Matcharashvili, Przyczyny, przebieg oraz skutki rosyjsko-gruzińskiego konfliktu z sierpnia 2008 roku. (Wojna 08.08.08. która nie wstrząnęła światem), rozprawa doktorska, Zakład Historii Wojskowości, Instytut Historii UAM, Poznań 2011, s. 112-113. S. Chazbijewicz podkreśla istnienie, w pewnym sensie, matrycy działań rosyjskich, zgodnych z maksymą Lwa Trockiego: „ani pokój, ani wojna”. Pretekstem do ingerencji zbrojnej jest ochrona interesów mniejszości (Abchazja, Osetia Południowa, Krym). Rosjanie doprowadzają do pokoju, ale pozostawiają sobie kontrolę nad danym terytorium, armia w sensie „sił pokojowych” zajmuje dany obszar w imię ochrony praw mniejszości. S. Chazbijewicz, O stosunkach..., op. cit., s. 10. 
W zjeździe prezydentów w Tbilisi wzięli udział prezydenci Litwy, Łotwy, Estonii Ukrainy, aktywnie wspomógł tę inicjatywę prezydent Azerbejdżanu, użyczając państwowych limuzyn do przewozu gości. Obecność delegacji prezydenckiej, także przewodniczącego Rady Europejskiej Nicolasa Sarkozy'ego wstrzymała działania wojsk rosyjskich, doprowadzając do zakończenia wojny. Przed budynkiem gruzińskiego parlamentu Prezydent RP wygłosił słynne przemówienie, krytykowane za zbyt wyrazisty przekaz antyrosyjski: „Jesteśmy tutaj, żeby wyrazić całkowitą solidarność (...). Jesteśmy po to, żeby podjąć walkę. Po raz pierwszy od dłuższego czasu nasi sąsiedzi (...) pokazali twarz, którą znamy od setek lat. Ci sąsiedzi uważają, że narody wokół nich powinny im podlegać. My mówimy „nie”! Ten kraj to Rosja. Ten kraj uważa, że dawne czasy upadłego niecałe 20 lat temu imperium wracają; że znów dominacja będzie cechą tego regionu. Otóż nie będzie. Te czasy się skończyły raz na zawsze"53.

L. Kaczyński nie przyjmował do wiadomości, iż wojna w Gruzji mogła zostać sprowokowana przez Gruzinów atakiem w Osetii Południowej, zdecydowanie opowiadał się za rosyjskim sprawstwem i istnieniem szerszego planu przewrotów w państwach kaukaskich, gdyż: „Rosjanie bardzo precyzyjnie przygotowali ten atak (...), był odpowiedzią na ciążenie Gruzji ku Zachodowi” i dalej: „winę za ten konflikt ponosi Rosja, to ona jest agresorem" ${ }^{54}$. Kilka lat później, w 2012 roku, wskutek konfliktów na poziomie elit rosyjskich, wyszło na jaw, iż wbrew wcześniejszym insynuacjom to nie Prezydent Gruzji Micheil Saakaszwili, ale W. Putin wydał rozkaz rozpoczęcia akcji militarnej w Gruzji, plan ataku istniał już w 2006 roku $^{55}$.

Podczas konfliktu w Gruzji razem z delegacją prezydencką przebywał minister spraw zagranicznych Radosław Sikorski, o którym prezydent L. Kaczyński powiedział: „często przyjmuje optykę narzuconą przez Rosjan”" ${ }^{56}$. Prezydenta i ministra dzieliła orientacja w polityce zachodniej, R. Sikorski był zdecydowanym zwolennikiem opcji prozachodniej i rozwiązania konfliktu rosyjsko-gruzińskiego tylko za pośrednictwem UE. L. Kaczyński krytycznie odnosił się nie tylko do zapatrywań ministra, lecz całego rządu, głównie z powodu wstrzymywania ogłoszenia stanowiska w sprawie bezpieczeństwa energetycznego oraz, jak twierdził, „niszczone są budowane od dłuższego czasu bardzo dobre stosunki

${ }^{53}$ Zob. pełny tekst przemówienia: Przemówienie na wiecu protestacyjnym $w$ Tbilisi przeciwko interwencji Rosji w Abchazji, 12 sierpnia 2008 roku, [w:] Warto być Polakiem..., op. cit., s. $62-63$.

${ }^{54}$ GK, PAP, „Rzeczpospolita”, op. cit.

${ }^{55}$ G. Kuczyński, Rosja zaplanowała atak na Gruzję. Putin przyznat się po czterech latach, https://www.tvn24.pl/, dostęp 29 X 2017.

${ }^{56}$ GK, PAP, „Rzeczpospolita”, op. cit. 
na Wschodzie" ${ }^{\text {57 }}$. W pierwszych dniach wojny wydawało się, iż dwa główne ośrodki władzy politycznej łączy zbieżność i wola współdziałania w obliczu tego konfliktu. W kolejnych, wskutek wzajemnych utarczek słownych, współpraca okazała się niemożliwa z ewidentną szkodą dla wizerunku Polski i możliwości oddziaływania na sytuację w regionie ${ }^{58}$.

\section{Ocena interwencji dyplomatycznej w Gruzji}

Wydarzenia gruzińskie pokazały, że polityka zagraniczna Unii ustalana jest między dwoma stolicami, Paryżem i Berlinem, inwestującymi w utrzymanie poprawnych stosunków z Rosją. W wyniku negocjacji pokojowych, prowadzonych w Genewie przez N. Sarkozy'ego i W. Putina, ustalono faktyczną kontrolę Rosji nad terytorium Gruzji, gdyż „Rosja dała do zrozumienia całemu światu, że dominuje w tym zapalnym regionie" ${ }^{59}$, uzyskując dostęp do wybrzeża Abchazji nad Morzem Czarnym oraz baz wojskowych Osetii w pobliżu rurociągów transportujących złoża z Morza Kaspijskiego. Oba kraje ogłosiły, nieuznawaną przez środowisko międzynarodowe, niepodległość, choć są w pełni kontrolowane przez Moskwę. Gruzja natomiast, także dzięki wydatnej pomocy Zachodu, rozpoczęła inwestycje w infrastrukturę dróg, celem wzmocnienia ruchu tranzytowego z państwami europejskimi ${ }^{60}$. Niekorzystnym dla niej skutkiem wojny jest znalezienie się w quasi-izolacji zewnętrznej ${ }^{61}$.

Treść rozejmu przemawia jednoznacznie za zakwalifikowaniem wojny w Gruzji jako politycznego fiaska delegacji prezydentów, jak i dyplomacji unijnej. Rosja jest jedynym zwycięzcą tego konfliktu i można stwierdzić, za Romanem Kuźniarem, iż W. Putin uzyskał w nim najważniejsze zakładane cele, tj.: 1) definitywnie rozstrzygnięto problem Abchazji i Osetii Południowej, faktycznie ustalając na tych terytoriach rosyjską dominację; 2) likwidacji uległ potencjał militarny Gruzji, tworzony przy wydatnym zaangażowaniu USA; 3) Rosja poprzez efekt demonstracji siły unaoczniła, iż na antyrosyjskie działania jest w stanie odpowiadać militarnie ${ }^{62}$. Natomiast bezsprzeczną zasługą Europy, przede wszystkim reprezentantów państw Europy Środkowo-Wschodniej, w tym głównie Prezy-

57 Ibidem.

${ }^{58}$ Idziemy na wojne..., op. cit.

${ }^{59}$ D. Brążkiewicz, op. cit.

${ }^{60}$ PAP, Rosyjskie straty i zyski rok po wojnie z Gruzja, https://www.wprost.pl/, dostęp 29 IX 2017.

${ }^{61}$ M. Wojciechowski, Spór o Lecha Kaczyńskiego. Prezydentura dobrych chęci, http://wyborcza.pl/, dostęp 27 IX 2017.

${ }^{62}$ R. Kuźniar, W Gruzji przegrali wszyscy, Polska też, http://www.newsweek.pl/, dostęp 25 IX 2017. 
denta RP, było wstrzymanie działań zbrojnych na terenie Gruzji, w konsekwencji zmniejszenie liczby ofiar i zniszczeń wojennych, a także zapobiegnięcie rozszerzeniu się konfliktu na państwa ościenne. W perspektywie globalnej konflikt w Gruzji ustalił granice wpływów Wschodu i Zachodu, zamroził też proces rozszerzania NATO o Gruzję i tym samym utrwalił zewnętrzne granice UE na najbliższy okres, poza nimi rozciąga się strefa imperialnych wpływów rosyjskich.

Występują rozbieżności w dyskursie publicznym w ocenie inicjatywy Prezydenta RP w sytuacji wojny rosyjsko-gruzińskiej w kontekście jej racjonalności i efektywności oraz rangę wspólnego przedsięwzięcia Polski, Litwy, Ukrainy, Estonii i Łotwy.

USA w oficjalnym stanowisku krytycznie oceniła działania Prezydenta Saakaszwilego, uznając za błąd użycie siły w odpowiedzi na prowokację Rosji. Natomiast obecność delegacji prezydenckiej jest oceniania jako kluczowa dla zaakceptowania zawieszenia broni i pokojowego porozumienia, bardzo niekorzystnego dla Gruzji, w zasadzie sankcjonującego rosyjską okupację ${ }^{63}$.

Aleksander Smolar twierdzi, iż „są jednak też polityczne i strategiczne kryteria sukcesu - w dłuższej perspektywie ważniejsze. Ważne jest, jakiego typu przesłanie niosła ta wizyta"64. Decyzja w sprawie Gruzji nie była poprzedzona konsultacjami z UE i USA, w związku z czym nie były one zobligowane do udzielania jej wsparcia w jakiejkolwiek postaci. Na pewno, co pokazał szczyt NATO w Bułgarii w 2008 roku, Europa nie posiada jednoznacznego stanowiska w tej kwestii. L. Kaczyńskiemu zarzucano „werbalny ekstremizm”, kierowanie słownych ataków pod adresem Rosji można zinterpretować jako niedostosowanie środków do celów politycznych i niepotrzebne zaognianie sytuacji ${ }^{65}$.

Zbieżny z tym stanowiskiem jest komentarz, w którym Aleksander Hall podkreślił, iż do niepowodzenia polityki wschodniej przyczyniła się sprzeczność między celami a rezultatami politycznymi, w efekcie której polityczne plany przyniosły odwrotne skutki. W obliczu odradzającego się ekspansjonizmu rosyjskiego działania powinien wyznaczać pragmatyzm, doprowadzając do wzmacniania istniejących już sojuszy politycznych w ramach UE z Niemcami i Francją. Konfrontacyjny styl uprawniania polityki niemieckiej nie zachęcał Rumunii,

${ }^{63}$ Wypowiedzi dla „Gazety Wyborczej” udzielił Matthew Bryza, amerykański dyplomata, między innymi mediator w konfliktach w Osetii Południowej i Abchazji oraz dyrektor ds. europejskich w Radzie Bezpieczeństwa Narodowego, odpowiedzialny między innymi za Kaukaz Południowy i Azję Środkową, a także zastępca specjalnego doradcy prezydenta i sekretarza stanu ds. kaspijskiej energii, A. Filipiak, Wspótpracownik Busha: Lech Kaczyński nie zatrzymat rosyjskich czotgów w Gruzji, http://wyborcza.pl/, dostęp 5 X 2017.

${ }^{64}$ Idziemy na wojnę..., op. cit.

${ }^{65}$ Ibidem. 
Litwy, Łotwy i Estonii do współpracy z Polską, natomiast Czechy i Węgry są zbyt prorosyjskie i także nie dążą do pogorszenia relacji z Niemcami ${ }^{66}$. Wynika stąd, iż prawdopodobieństwo powodzenia polityki wschodniej wzrosłoby przy jednoczesnym zachowaniu dobrych relacji z Niemcami.

Natomiast krytyczna w ocenie polityki zagranicznej L. Kaczyńskiego jest opinia R. Kuźniara: „Postępowanie prezydenta było dobrą ilustracją jego politycznego światopoglądu, w tym niechęci do rzetelnego oglądu rzeczywistości"67. Podkreśla on zasadność interwencji dyplomatycznej, łączenie interesów Polski i wsparcia dla Gruzji, ale za błędne decyzje uważa podróż i dosadność wypowiedzi L. Kaczyńskiego w Tbilisi. Przewidywał, iż bezpośrednim skutkiem będzie pogorszenie stosunków z Rosją, załamanie polityki wschodniej i utrata wiarygodności w UE ${ }^{68}$. Krytyczni są także Mariusz Janicki i Wiesław Władyka, sytuując aktywność L. Kaczyńskiego w Gruzji na poziomie polityk regionalnych i nadając jej miano „wewnętrznej polityki zagranicznej”, nawiązującej do tradycji patriotycznych powstania warszawskiego, pozbawionej odpowiedzialności politycznej i pragmatyzmu, nieracjonalnej, zaogniającej stosunki z Rosją, a przede wszystkim nastawionej na odbiorcę w kraju, czyli elektorat rodzimej partii: „Taka polityka może być jednak zwycięska na poziomie werbalnym" ${ }^{69}$.

Poza tym krytycznym trendem występuje szereg opinii pozytywnych, także ze strony antagonistów L. Kaczyńskiego. Adam Michnik docenił zaangażowanie Prezydenta RP w konflikcie rosyjsko-gruzińskim, akcentując wartości, jakie ze sobą niosła: „Pierwszy raz poczułem się dumny z tego, że prezydent mojego państwa w tak godny sposób, a zarazem tak zgodny z polskim i moim wyobrażeniem etosu wolności, honoru, tradycji historycznej i rozumu politycznego dał temu wyraz w Gruzji. Kaczyński zrobił maksimum tego, co mógł w tym momencie zrobić (...). W takiej sytuacji należy szukać nadzwyczajnych odpowiedzi. I Kaczyński ją znalazł"70. A. Dudek uważa, że pozostanie ona jednym z „najważniejszych dokonań jego prezydentury"71. Natomiast Selim Chazbijewicz twierdzi, że zaangażowanie Polski w konflikt rosyjsko-gruziński „nie jest kaprysem prezydenta Kaczyńskiego, a ma dla nas kluczowe strategiczno-polityczne znaczenie" ${ }^{\text {"72 }}$.

\footnotetext{
${ }^{66}$ A. Hall, Putin może zacierać ręce, „Więź”, 2016, 2(664), s. 165-167.

${ }^{67}$ R. Kuźniar, op. cit.

${ }^{68}$ Ibidem.

${ }^{69}$ M. Janicki, W. Władyka, Wewnętrzna polityka zagraniczna, http://www.polityka.pl/,

${ }^{70}$ A. Michnik, Polska zdała gruziński egzamin, http://wyborcza.pl/, dostęp 28 IX 2008,

${ }^{71}$ A. Dudek, O prezydenturze..., op. cit.

${ }^{72}$ S. Chazbijewicz, O stosunkach..., op. cit., s. 10.
} dostęp 24 IX 2017. 
Racjonalna, uwzględniająca wieloaspektowość polskiej interwencji dyplomatycznej w Gruzji w kontekście polityki wschodniej, jest wypowiedź Zdzisława Najdera: „Uprawianie polityki powinno oznaczać przełożenie założeń i celów na język konkretnych poczynań, na sieć szczegółowych, skoordynowanych decyzji merytorycznych i organizacyjnych"73. Zasługą Prezydenta RP jest podjęcie realnej współpracy w regionie w kwestii bezpieczeństwa energetycznego i uniezależnienia się od dostaw ropy i gazu z Rosji, efektem jest podpisanie umowy dotyczącej rurociągu Odessa-Brody-Płock-Gdańsk, pierwszego łączącego basen Morza Kaspijskiego i Czarnego z Morzem Bałtyckim, a także stworzenie tras przesyłania gazu ${ }^{74}$. Cele polityczne Prezydenta wymagałyby rozłożenia w czasie na co najmniej dekadę. Czynnikiem niesprzyjającym w ich realizacji podczas pierwszej, niedokończonej kadencji, był okres kohabitacji. Premier i Minister Spraw Zagranicznych posiadali odmienne priorytety polityki regionalnej, przedkładając współpracę w ramach unijnych struktur i dobre relacje z Rosją ponad sojusz środkowoeuropejski. Przypadek Gruzji utwierdził środowisko międzynarodowe w przekonaniu, iż Rosja nie dostrzega potrzeby budowania partnerstwa z Europą, tym bardziej z Polską. Jako konkluzję tej części podrozdziału można przytoczyć opinię L. Kaczyńskiego, odpowiedź na pytanie o politykę wschodnią: „Wie pan, to nie jest takie proste. Ci prezydenci (z Europy Wschodniej - D.L-L.) połapali się, że ode mnie niewiele zależy, i nie bardzo chcą się teraz angażować w te sprawy"75.

\section{Podsumowanie}

Politykę zagraniczną L. Kaczyńskiego wyznaczały dwie osie, pierwsza wschodnia, kreślona przez Rosję, druga - zachodnia, determinowana działaniami unijnych partnerów. Pochodną ich wzajemnych oddziaływań było konceptualne wyodrębnienie punktów newralgicznych w polityce zagranicznej, takich jak na przykład Ukraina czy Gruzja, wyraźnie akcentowanych w programach rodzimej partii L. Kaczyńskiego, realizowanych w działaniach politycznych w okresie jego prezydentury. Argumentów przemawiających za determinacją w realizacji polityki wschodniej dostarczała kultura strategiczna państwa polskiego, z dominującym przekonaniem o odnawianiu się rosyjskiej polityki imperial-

${ }^{73}$ Cyt. za: K. Rak, „Jesteśmy podmiotem!” - Lecha Kaczyńskiego polityka regionalna, http:// wiadomosci.onet.pl/, dostęp 2 X 2017.

${ }^{74}$ Wspólna deklaracja Prezydentów po szczycie energetycznym w Krakowie, 11 maja 2007 roku, Warto być Polakiem. Idea i myśl Lecha Kaczyńskiego, oprac. zbior., Wydawnictwo KPRP, Warszawa 2010, s. 61.

${ }^{75}$ M. Wojciechowski, Spór o Lecha..., op. cit. 
nej, zmierzającej do utrwalenia stref wpływów przy jednoczesnym zachowaniu pozornej niezależności i suwerenności państw zdominowanych przez Rosję.

Nie wydaje się, by w pełni uprawnione były głosy o ułomności koncepcji polityki wschodniej L. Kaczyńskiego, ale „starcie z gigantem”, Rosją restytuującą swoje imperialne tradycje, nie mogło zakończyć się pozytywnie bez silnego wsparcia ze strony USA i UE. Pytaniem otwartym pozostaje kwestia możliwych scenariuszy konfrontacji Wschodu z Zachodem w kontekście przypadku gruzińskiego, jak i sama zasadność stawiania takich pytań.

Polsce nieposiadającej szczególnie istotnych zasobów (poza potencjałem ludnościowym), umożliwiających jej samodzielne rozgrywanie poszczególnych partii w polityce zewnętrznej, z dyskusyjnie korzystnym bądź dyskusyjnie niekorzystnym położeniem geopolitycznym, nie pozostawało nic innego jak odgrywanie znaczącej roli w polityce regionalnej. Polska jest krajem średniej wielkości i pod tym względem ma ograniczone możliwości skutecznego wpływu na stosunki międzynarodowe, tak ze względu na posiadanie niewystarczającej ilości środków oddziaływania, jak i zbyt nikłego potencjału do pełnienia roli istotnego podmiotu w wymiarze globalnym czy uniwersalnym. Natomiast może pełnić ważną rolę w partnerstwie lokalnym, z państwami sąsiadującymi lub oddalonymi geograficznie, z którymi prowadzi zaawansowaną współpracę w różnych dziedzinach. Polska odgrywa zatem role regionalne i subregionalne. Pod względem efektywności deklarowana rola propagatora demokracji na wschód Europy, do państw postradzieckich, nie zakończyła się oczekiwanym spektakularnym sukcesem, choć na jej niepowodzenie nie złożyła się nieudolność polskiej polityki, raczej brak otwartości i chęci dynamicznych zmian po stronie adresatów tej inicjatywy ${ }^{76}$. Nie konfrontacyjnie, ale poprzez dialog i pozytywne doświadczenia, wynikające ze współpracy, wiedzie droga pokojowego współistnienia w środowisku międzynarodowym, zwłaszcza że Rosja posiada skłonność do siłowego rozwiązywania sporów. Przypadek gruziński tak naprawdę zniweczył politykę wschodnią i przywołał doświadczenia historyczne. To incydentalne wydarzenie posiadało jednoznaczny przekaz, iż nie jest racjonalne, a wkraczanie w sferę interesów rosyjskich grozi nawet utratą stabilizacji i bezpieczeństwa.

${ }^{76} \mathrm{~J}$. Zając, Role międzynarodowe państwa średniego - aspekty teoretyczne, „Krakowskie Studia Międzynarodowe", 2013, 4, s. 25. 


\section{Wykaz źródeł i literatury}

\section{Źródła}

- IV Rzeczpospolita. Sprawiedliwość dla Wszystkich, Prawo i Sprawiedliwość. Program 2005 r., http://old.pis.org.pl/dokumenty, dostęp 15 IX 2017.

- Dbamy o Polaków, Prawo i Sprawiedliwość, Program 2007, http://old.pis.org.pl/ dokumenty, dostęp 15 IX 2017.

- Dudek A., Głównym terenem rywalizacji prezydenta Lecha Kaczyńskiego i rzadu Donalda Tuska stała się polityka zagraniczna, https://wpolityce.pl/, dostęp 9 X 2017.

- Dziennik Ustaw, nr 141, poz. 943; nr 122, poz. 1344.

- Filipiak A., Wspótpracownik Busha: Lech Kaczyński nie zatrzymat rosyjskich czołgów w Gruzji, http://wyborcza.pl/, dostęp 5 X 2017.

- GK, PAP, „Rzeczpospolita”, Z Rosja trzeba ostro. Rozmowa z Prezydentem Lechem Kaczyńskim, http://www.newsweek.pl/, dostęp 17 X 2017.

- Henzel P., Wracaja kontrowersje wokót szczytu NATO w Bukareszcie. „Nowa linia podziału” w Europie, http://wiadomosci.onet.pl/, dostęp 22IX 2017.

- Idziemy na wojnę z Rosją? Z Aleksandrem Smolarem rozmawiał Adam Leszczyński, http://wiadomosci.gazeta.pl/, dostęp 30 IX 2017.

- Janicki M., Władyka W., Wewnętrzna polityka zagraniczna, http://www.polityka.pl/, dostęp 24 IX 2017.

- Konstytucja Rzeczypospolitej Polskiej z dnia 2 kwietnia 1997 roku, www.sejm.gov.pl/, dostęp 25 IX 2017.

- Kuczyński G., Czy NATO otworzy się na Wschód?, https://www.tvn24.pl/, dostęp 25 IX 2017.

- Kuczyński G., Tomaszewski M., Szczyt NATO w Bukareszcie, https://www.tvn24.pl/, dostęp 22 IX 2017.

- Kuźniar R., W Gruzji przegrali wszyscy, Polska też, http://www.newsweek.pl/, dostęp 20 IX 2017.

- Michnik A., Polska zdała gruziński egzamin, http://wyborcza.pl/, dostęp 28 IX 2018.

- Nowoczesna, solidarna, bezpieczna Polska. Program Prawa i Sprawiedliwości, Materiały KW Prawo i Sprawiedliwość, Wydawnictwo Prawo i Sprawiedliwość, Kraków 2009.

- Orzeczenie TK z 20 maja 2009 r., Kpt 2/08, http://trybunal.gov.pl, dostęp 10 X 2017.

- PAP, Rosyjskie straty i zyski rok po wojnie z Gruzja, https://www.wprost.pl/, dostęp 29 IX 2017.

- Przemówienie inauguracyjne Prezydenta RP Lecha Kaczyńskiego z dnia zaprzysiężenia na Prezydenta RP z dnia 23.12.2005 r., [w:] Warto być Polakiem. Idea i myśl Lecha Kaczyńskiego, oprac. zbior., Wydawnictwo KPRP, Warszawa 2010.

- Przemówienie na uroczystości odsłonięcia i poświęcenia pomnika ku czci ofiar tragedii w Pawłokomie na Rzeszowszczyźnie, 13 maja 2006 roku, [w:] Warto być Polakiem. Idea i myśl Lecha Kaczyńskiego, oprac. zbior., Wydawnictwo KPRP, Warszawa 2010.

- Przemówienie na wiecu protestacyjnym w Tbilisi przeciwko interwencji Rosji w Abchazji, 12 sierpnia 2008 roku, [w:] Warto być Polakiem. Idea i myśl Lecha Kaczyńskiego, oprac. zbior., Wydawnictwo KPRP, Warszawa 2010. 
- Rak K., „Jesteśmy podmiotem” Lecha Kaczyńskiego polityka regionalna, http://wiadomosci.onet.pl/, dostęp 2 X 2017.

- Romaniec R., Bilans szczytu NATO w Bukareszcie, http://www.dw.com/pl/, dostęp 22 X 2017.

- Wojciechowski M., Spór o Lecha Kaczyńskiego. Prezydentura dobrych chęci, http:// wyborcza.pl/, dostęp 27 IX 2017.

- Wspólna deklaracja Prezydentów po szczycie energetycznym w Krakowie, 11 maja 2007 roku, Warto być Polakiem. Idea i myśl Lecha Kaczyńskiego, oprac. zbior., Wydawnictwo KPRP, Warszawa 2010.

- Wystapienie pod pomnikiem Polegtych i Pomordowanych na Wschodzie w Warszawie, 17 września 2009 roku, Warto być Polakiem. Idea i myśl Lecha Kaczyńskiego, oprac. zbior., Wydawnictwo KPRP, Warszawa 2010.

\section{Piśmiennictwo naukowe}

- Banaszak B., Prawo konstytucyjne, Warszawa 2001.

- Brążkiewicz D., Wojna rosyjsko-gruzińska, http://www.geopolityka.org/

- Chazbijewicz S., Dlaczego Gruzja? Relacje polsko-gruzińskie wczoraj i dziś, Debata, nr 6 (9) 2008.

- O stosunkach polsko-gruzińskich, „Debata”, nr 9(12) 2008.

- Dudek A., O prezydenturze Lecha Kaczyńskiego, http://muzhp.pl/

- Garlicki L., Konstytucja a „sprawy zewnętrzne”, „Przegląd Sejmowy”, 2007, nr 4.

- Polskie prawo konstytucyjne. Zarys wyktadu, Wolters Kluwer, Warszawa 2009.

- Grzybowski M., System rządów w Rzeczypospolitej Polskiej: charakterystyka i diagnoza watpliwości. Uwagi wprowadzajace, „Przegląd Prawa Konstytucyjnego”, 2012, 1.

- Hall A., Putin może zacierać ręce, „Więź”, 2(664), 2016.

- Jaskiernia J., Współdziałanie Prezydenta i Rady Ministrów w sferze polityki zagranicznej, „Państwo i Prawo”, 2010, 6.

- Masternak-Kubiak M., Preisner A., Realizacja podziału kompetencji organów państwa w stosunkach zewnętrznych, [w:] Otwarcie Konstytucji RP na prawo międzynarodowe i procesy integracyjne, red. K. Wojtowicz, Wydawnictwo Sejmowe, Warszawa 2006.

- Matcharashvili I., Przyczyny, przebieg oraz skutki rosyjsko-gruzińskiego konfliktu z sierpnia 2008 roku. (Wojna 08.08.08 która nie wstrzasnęła światem), rozprawa doktorska, Zakład Historii Wojskowości, Instytut Historii UAM, Poznań 2011.

- Mażewski L., Prowadzenie polityki zagranicznej w Rzeczypospolitej Polskiej, „Ruch Prawniczy, Ekonomiczny i Socjologiczny”, 2009 R. LXXI, z. 3.

- Ochmann P., Pisz M., Aksjologiczne fundamenty konstytucji Rzeczypospolitej Polskiej, [w:] Prawo konstytucyjne. Kompendium, red. R. Piotrowski, Wydawnictwo C.H. Beck, Warszawa 2014.

- Paruch W., W obronie interesów narodowych i tożsamości politycznej Europy Środkowo-Wschodniej. Eurorealizm w myśli politycznej Prawa i Sprawiedliwości, [w:] „Rodzinna Europa”. Europejska myśl polityczno-prawna u progu XXI weku, red. P. Fiktus, H. Malewski, M. Marszał, E-Wydawnictwo. Prawnicza i Ekonomiczna Biblioteka Cyfrowa, Wrocław 2015.

- Sarnecki P., Komentarz do art. 126, [w:] Konstytucja Rzeczypospolitej Polskiej. Komentarz, t. I, red. L. Garlicki, Wydawnictwo Sejmowe, Warszawa 1999. 
- Snyder J., The Soviet Strategic Culture: Implications for Limited Nuclear Operations, RAND Publication, Santa Monica 1977.

- Warzecha Ł., Lech Kaczyński - ostatni wywiad, Prószyński i S-ka, Warszawa 2010.

- Włodarczyk M., Stosunki polsko-gruzińskie w latach 1918-1921, „Świat Idei i Polityki”, 2016, t. 15 (26).

- Włodkowska-Bagan A., Konfliktowość w stosunkach polsko-rosyjskich jako stygmat geopolityczny, [w:] Geopolityka w stosunkach polsko-rosyjskich, red. S. Bieleń, A. Skrzypek, Oficyna Wydawnicza ASPRA-JR, Warszawa 2012.

- Kultura strategiczna Polski, [w:] Polityka zagraniczna Polski w zmieniajacym się tadzie międzynarodowym: wybrane problemy, red. R. Zięba, T. Pawluszko, Wydawnictwo UJK, Kielce 2016.

- Zając J., Role międzynarodowe państwa średniego-aspekty teoretyczne, „Krakowskie Studia Międzynarodowe", 2013/2014.

Streszczenie: W tekście dokonano analizy efektywności działań podejmowanych przez Prezydenta RP Lecha Kaczyńskiego w kontekście jego zaangażowania w konflikt rosyjsko-gruziński z 2008 roku. Uwzględniono sytuację geopolityczną Polski, prerogatywy Prezydenta RP w dziedzinie stosunków zewnętrznych, koncepcję i uzasadnienie polityki wschodniej oraz ocenę interwencji dyplomatycznej w Gruzji. W konkluzji stwierdzono zasadność strategicznego partnerstwa polskogruzińskiego, przy jednoczesnym występowaniu determinant uniemożliwiających jego realizację.

Słowa kluczowe: Lech Kaczyński, polityka wschodnia, konflikt rosyjsko-gruziński

Georgian Episode of Polish Foreign Policy During the Presidency of Lech Kaczyński (2005-2010)

Summary: The text analyzes the effectiveness of actions taken by the President of Poland Lech Kaczyński in the context of his involvement in the Russian-Georgian conflict of 2008. The geopolitical situation of Poland, the prerogatives of the President of the Republic of Poland in the field of external relations, the concept and justification of Eastern policy, and the assessment of diplomatic intervention in Georgia were taken into account. The conclusion was that the strategic partnership between Poland and Georgia was justified, while at the same time there was a determinant which made it impossible to implement it.

Keywords: Lech Kaczyński, Eastern Policy, Russian-Georgian conflict 